\title{
Histological and Histochemical Changes on Gonads of Sea Bass Fish as Consequence of Water Pollution
}

\author{
Nermin El-Morshedi ${ }^{1 *}$, Nadeem A. Kizilbash ${ }^{2}$, Ahmed Abdeen ${ }^{3}$, Abd-Allah \\ El-Shebbly ${ }^{4} \&$ Ahmed El-Berri ${ }^{5}$ \\ (1) Department of Anatomy and Histology, Faculty of Medicine \& Applied Medical Sciences, Northern \\ Border University, Arar-91431, Saudi Arabia. \\ (2) Department of Biochemistry, Faculty of Medicine \& Applied Medical Sciences, Northern Border \\ University, Arar-91431, Saudi Arabia. \\ (3) Department of Zoology, Faculty of Science, Mansoura University, Egypt. \\ (4) National Institute of Oceanography and Fisheries, Alexandria, Egypt. \\ (5) Egyptian Environmental Affairs Agency, Egypt.
}

\begin{abstract}
Lake Manzalah is the most important lake in Egypt as it provides about 30\% of domestic fish supply, but is affected by drainage water. Lake Bardawil is the least polluted wetland in Egypt as is considered protected area. So, it is selected as the control lake in the study. Water and fish samples were taken at the same time (winter, 2012), from the two lakes. Lake Manzalah water have higher concentration levels (ppm) of studied heavy metals: Chromium, Lead and Cadmium and their levels exceeded the recorded safety limits in the two Egyptians environmental laws; No. 48/1982 and No. 4/1994. Histologically, Lake Manzalah fish testes showed a delaying in process of spermatogenesis, disruption of spermatogenic cells and reduction in spermatids. Lake Manzalah fish ovaries affected by heavy metal pollutions as atresia, deformed zona radiata, necrotic oocytes and broken tunica albuginea were presented. Histochemically, testicular and ovarian tissues of Lake Manzalah fish samples showed decreasing in total polysaccharide, protein and DNA and RNA contents due to severe affection of toxicant heavy metals. The collagen fibers increased in Lake Manzalah testicular samples as intersetial cells collapsed sperm nests, but the collagen fiber in ovarian tunica albuginea composition was weak and broken. The present study showed accumulated toxic heavy metals in Lake Manzalah water which implied on fish gonads and impair their reproduction. We recommended for improving water quality control and periodically environmental monitoring in El-Manzalah lake.
\end{abstract}

Key words: Heavy metals, pollution, Histology, Histochemical studies, sea bass.

Abbreviations: Chromium (Cr), Lead ( $\mathrm{Pb}$ ) and Cadmium (Cd).

\section{Introduction}

Seafood is consumed by a large segment of Egypt population. Fish represent one of the most important and cheapest sources of protein. Lake Bardawil is one of the most important lakes in Egypt as a source of a good quality fish and a habitat for the wildlife as the lake is considered a protected area (El-Bawaab, 1995). Lake Manzalah is economically the most important Delta lake in Egypt. It provides about $30 \%$ of the domestic fish supply (Abd El-Hakim et al., 1999). Manzalah lake is affected by sewage effluents, agricultural and industrial drainage water (El-Shebly, 1998), which make the lake highly polluted with toxic heavy metals (Alne, 1998). Heavy metals pollutants were found to be more dangerous to the environment (Phillips, 1991). Some of them are essential that are required for the normal metabolism of organisms as $\mathrm{Cu}, \mathrm{Fe}$ and $\mathrm{Zn}$, while others are nonessential and play no significant biological role as $\mathrm{Cr}, \mathrm{Pb}$ and $\mathrm{Cd}$ (Sanders, 1997). Non-essential heavy metals natural effects could be toxic (acute, chronic or sub-chronic), carcinogenic, mutagenic or teratogenic (Young, 2005). They may also alter genetic structure (Roark and Brown, 1996). The present study deals with sea bass fish (Dicentrarchus labrax) which belonged to order Mugiliformes, family Moronidae (McDonough and Wenner, 2003). The study illustrates heavy metal pollution effect on fish reproductive ability according to histological and histochemical results.

\section{Material And Methods}

Samples of water and sea bass fish (Dicentrarchus labrax) were collected from Lake Bardawil (control lake) as it is a protected area and Lake Manzalah (polluted lake) for further study at the same time (Summer, 2012). $\mathrm{Cr}, \mathrm{Pb}$ and $\mathrm{Cd}$, measurements were analyzed using flame atomic absorption spectrophotometer with an air acetylene flame (Model 2380, Perkin-Elmer) (Zottner and Seligson, 1964). Statistical analysis were performed by using Student t-test according to Murray (1982). Fish from the studied areas were dissected for gonads inspection (testes and ovaries). Specimens were fixed in 10\% saline formalin, dehydrated in ascending 
series of alcohol and embedded in paraffin wax. Serial transverse sections at $5 \mu \mathrm{m}$ and stained by HaematoxylinEosin (Weesner, 1968 and Clayden, 1971). Total polysaccharides: and protein contents were identified according to Causan and Pickett (1983) and Launa (1968) respectively. Masson's Trichrome staining Method was applied for collagen fibers (Masson, 1929) and RNA and DNA contents detection, was by methyle Green pyronin Y method (Kurnick, 1955).

\section{Heavy metals in water:-}

III. Results

Table 1 shows a comparison between the mean concentration levels (ppm), standard deviation and standard error of studied heavy metals $(\mathrm{Cr}, \mathrm{Pb}$ and $\mathrm{Cd})$ in Lake Bardawil water and Lake Manzalah water. Lake Manzalah display the highest concentration levels (ppm) of studied heavy metals. According to safety limits in the two Egyptian environmental laws No. 48/1982 and No. 4/1994, the mean concentration levels of $\mathrm{Cr}, \mathrm{Pb}$ and $\mathrm{Cd}$ are comparatively exceeded the recorded safety limits in Lake Manzalah water and showed higher significant differences between both lakes.

\section{Histological and histochemical alterations:-}

\subsection{Testes:}

Histologically, Dicentrarchus labrax testes which were caught from Lake Bardawil showed seminiferous tubules with intensive spermatogenesis, reduced number of spermatogonia and numerous of spermatozoa. Accordingly, numerous of primary, secondary spermatocytes, numerous of the smaller deeply stained spermatids were seen with obvious increasing in their number (Figure 1). D. labrax testes which were caught from Lake Manzalah showed decreased number of seminiferous tubules with some degenerative changes. They appeared empty from different spermatogenic cells (primary and secondary spermatocytes). The interstitial cells were collapsed and appeared small in size and attacked all seminiferous tubules nests. Accordingly, seminiferous tubules showed fewer number of spermatids and sperms nests and appeared radiated without any inside septa between their nests (Figure 2). collectively, seminiferous tubules showed a marked blocking in spermatogonial mitosis and delaying in transformation of the spermatids to mature spermatozoa (sperms).

Histochemically, D. labrax testicular tissues which were collected from Lake Bardawil exhibited a strong PAS reaction for polysaccharides (Figure 3), a strong protein staining affinity after application of mercury-bromophenol blue staining method (Figure 5) and a strong RNA and DNA contents by applying methyle green pyronin Y stain (Figure 7) when compared by D. labrax testicular tissues which were collected from Lake Manzalah as exhibited a light affinity (Figure 4, Figure 6 and Figure 8). Oppositely, D. labrax testicular tissues which were collected from Lake Manzalah showed a strongly reaction for collagen fiber contents by masson stain applying (Figure 10), but there was a weak reaction of collagen fiber contents by masson stain applying (Figure 9) in D. labrax testicular tissues which were collected from Lake Bardawil. These collagen fibers when increased as that in Lake Manzalah samples is due increasing the intersetial cells which collapsed the sperm nests.

\subsection{Ovaries:}

D. labrax ovaries which were caught from Lake Bardawil showed different stages of oogenesis were presented as chromatin-nucleolus stage, early and late peri-nucleolar stages. There was clearly appeared for cortical alveoli (Figure 11). At these stages oocytes increased in size and enveloped by follicular epithelia and vitelline membrane (zona radiate) which was as a protective boundary for oviplasm (ooplasm). Beginning of vitellogenetic stage (lipid-yolk vesicles stage), was noticed. In this stage, there were vitellogensis process increasing, lipid vesicles increasing in oviplasm and a massive accumulation of yolk protein occupying oocytes central portion as yolk spheres so, oocytes reached its maximal size. The vitelline membrane (zona radiate) was clearly visible between oviplasm and follicular layer (granulose cell layer and theca cell layer) as they were called zona granulose (Figure 11). D. labrax ovaries which were caught from Lake Manzalah were affected by heavy metals as atresia (degeneration), deformed zona radiata besides its segmentation, broken down and proliferation of follicular cells were shown in D. labrax ovaries which were caught from Lake Manzalah. Necrotic oocytes were noticed in the majority of germ cells and deformed the surrounding cytoplasm. There was a distinctive yolk and cytoplasm became highly vacuolated. Also, broken tunica albuginea was seen at all sites (Figure 12).

Histochemically, D. labrax ovarian tissues which were collected from Lake Bardawil exhibited a strong PAS reaction for polysaccharides (Figure 13), a strong RNA and DNA contents by applying methyle green pyronin Y stain (Figure 17), a strong protein staining affinity after application of mercury-bromophenol blue staining method (Figure 15) and a strong reaction for the collagen fiber contents by masson stain applying (Figure 19) when compared by D. labrax ovarian tissues which were collected from Lake Manzalah as exhibited 
a light affinity (Figure 14, 16, 18 and 20 respectively). The collagen fiber is according to ovarian tunica albuginea composition as it is weak and broken in Lake Manzalah tissue samples.

\section{Discussion}

In Egypt, the pollution of the aquatic habitats seems to be an inevitable problem. In recent years, more toxic compounds are being increasingly detected in the aquatic ecosystem (Khare and Singh, 2002). Heavy metals are natural trace components of the aquatic environment (Al-Weher, 2008), but their concentration levels have increased due to industrial, agricultural and mining activities and are contributed to aquatic ecosystems pollution (Canli and Atli, 2003). Some heavy metals are essential as $\mathrm{Fe}, \mathrm{Zn}$ and $\mathrm{Cu}$ and necessary in trace concentrations for normal growth and development (Kalay and Canly, 2000). However, other non-essential heavy metals as $\mathrm{Pb}, \mathrm{Cd}$ and $\mathrm{Cr}$ even at low concentrations are very toxic to human health and aquatic organisms (Jayakumar and Paul, 2006). Once these heavy metals are accumulated in aquatic organism; they are transferred through upper classes of food-chain. Human, obtain most of his heavy metal contaminations from aquatic ecosystem by the way of his fish food (Langston, 1990). Heavy metals have toxic effects on fish tissues and altering tissue histological structures, and cause many physiological, reproduction and growth defects (Weis and Weis, 1989). Heavy metals may have direct effects on fish gonads (testes and ovaries), resulting in a disturbed germ cells development (Mohamed and Gad, 2008).

In the present study, the mean concentration levels of $\mathrm{Cr}, \mathrm{Pb}$ and $\mathrm{Cd}$ in Lake Manzalah water (0.2450.0945-0.065 (ppm), respectively) were extremely higher than the permissible concentration levels recorded by Egyptian Standards of Environmental Laws No. 48/1982 and No. 4/1994 which stated that the maximum concentration levels of $\mathrm{Cr}, \mathrm{Pb}$ and $\mathrm{Cd}$ in water should not exceed 0.001-0.01-0.05 (ppm), respectively. These observations, showed that there were accumulated heavy metals in Lake Manzalah water. Cd exposure was linked with renal failure, bone fragility as osteoporosis and is considered as a cancer causing agent (ATSDR, 2004). The adverse toxic effect of $\mathrm{Pb}$ on human health particularly children was recognized (Subramanian, 1988). In addition, neurological defects, renal tubular dysfunctions and anemia, are the most popular toxic effect of $\mathrm{Pb}$ poisoning (Forstner and Wittman, 1983). Cr complexes, which are bounded to other lower molecular weight legends, are mostly traversed to the cell membrane (Mertz, 1969). Once $\mathrm{Cr}$ enters the cell, it interacts with cellular macromolecules, including DNA, or slowly released from the cell and causes human carcinogen (Wiegand et al., 1985). The toxicity of heavy metals was presented as a disruption in gonadal development (testes and ovaries) (Gordon et al., 2000).

According to the present results, Lake Manzalah environmental impacts caused a pronounced decline in gonad activity of the studied fish. This result was reflected clearly by decreasing sperm and spermatids counting in ripe testes and ripe oocytes degeneration (atresia). According to reported document of Phillips (1991), histological changes in testes were progressively increased with increasing the concentration levels of heavy metal pollutions. Histochemically, D. labrax testicular tissues which were collected from Lake Manzalah showed inhibition of the total polysaccharides and total protein, also, DNA and RNA contents, but increasing in collagen fibers composition due to severe effect of heavy metals pollution when compared with those collected from Lake Bardawilfish samples. Subsequently, the amount of the PAS-positive materials and mercurybromophenol blue stained materials in the tissues indicated the degree of the total polysaccharide and protein contents in the testicular tissues. Besides that DNA and RNA contents and collagen fibers content (Chandra and Khuda, 2004).

The cycle changes in D. labrax oocytes was divided into five stages namely: chromatin nucleolar, perinulceolar, yolk vesicle, vitellogenic and ripe (mature) stage (Alne, 1998). In the study, pre-nucleolus stage was characterized by small size of oocytes. The end of this stage, is late per-nucleolus stage which distinguished by oocyte enlargement, oocyte primitive wall was composed of one thin layer of flattened follicular cells (Zaki et al., 1993). The second growth phase which is vitellogenic stage included yolk vesicle stage and was characterized by vacuoles in circular manner around nucleus and surrounding cytoplasm and oocyte wall is consisted of two layers: an externally situated zona granulose and an internally located zona radiata layer near the cytoplasm (Yammamoto and Yoshioka, 1964). There were appearance of marked degenerative changes in female specimens oocytes from Lake Manzalah, the surrounding cytoplasm was greatly deformed and a distinctive form of yolk, and cytoplasm was greatly changed and appeared highly vacuolated. Also, broken tunica albuginea was spread at all sites (Hatikakoty, 2002). The degree of maturation of oocytes from female fishes from Lake Bardawil was found higher than those obtained from in Lake Manzalah. Histochemically, the ovarian tissues of the studied fish collected from Lake Manzalah gave a clear information about the internal changes in the total polysaccharide and total protein contents, also, DNA and RNA contents and collagen fibers composition which resulted from the severe effect of the heavy metal pollution, when compared with those collected from Lake Bardawil as it is a protected area (Mousa and Mousa, 1999).

In conclusion, The present study documented that improvement of water quality control and periodically environmental monitoring are necessary in El-Manzalah lake water. In addition, there are many 
recommendations from health authorities for regarding the acceptable number of the consumed fish meals, which hunted from El-Manzalah lake to prevent the accumulative effects of heavy metals (Ahmed and Hussein, 2004). In Egypt, although there are a marked reduction in heavy metal contents in El-Manzalah lake when compared to the past few years, more governmental efforts still needed to control the environmental pollution and improve its water quality.

\section{References}

[1]. Abd El-Hakim, F.; Azab, M.; Emam, M. and Sherif, Y. (1999). Fishery assessment of Lake Manzalah. Egypt. J. Aquat. Biol. Fish., 3: 539-564.

[2]. Agency for Toxic Substances and Disease Registry (ATSDR) (2004). Agency for Toxic Substances and Disease Registry, Division of Toxicol., 123-130.

[3]. Ahmed, A. and Hussin, M. (2004). Residual levels of some heavy metals in fish flesh and water from El-Manzalah lake, Egypt. J. King Saud Univ. Agric. Sci., 16: 187-196.

[4]. Alne, A. (1998). Studies on the oogenesis of the Nile Mormyrid fish, Pollimyrus isidori. J. Egypt. Ger. Soc. Zool., 30: 23-38.

[5]. Al-Weher, M. (2008). Levels of Heavy Metal Cd, $\mathrm{Cu}$ and $\mathrm{Zn}$ in Three Fish Species Collected from the Northern Jordan Valley, Jordan. J. Vet. Anim. Sci.,1:41-46.

[6]. Canli, M. and Atli, G. (2003). The relationships between heavy metal $(\mathrm{Cd}, \mathrm{Cr}, \mathrm{Cu}, \mathrm{Fe}, \mathrm{Pb}, \mathrm{Zn})$ levels and size of six Mediterranean fish species. Environ. Poll. Sci. Total Environ., 121: 129-136.

[7]. Causon, F. and Pickett, J. (1983). Histochemistry, Race, G. (ed.)., Laboratory Medicine. Philadelphia,, 23-30.

[8]. Chandra, P. and Khuda-Bukhsh, A. (2004). Genotoxic effects of cadmium chloride and azadirachtin treated singly and in combination in fish. Ecotoxicol. Environ. Saf., 58: 194-201.

[9]. Clayden, B. (1971). Practical Section Cutting and Staining. Churchill Livingstone, Edinburgh, London.

[10]. El-Bawaab, M. (1995). Bardawil Lake, Extensions Bulletin Series. Bulletin., 21:20-25.

[11]. E1-Shebly, A. (1998). Heavy metal content in some tissues of Nile Tilapia (Oreochromis niloticus) from EL-Manzalah fish farm. J. Egypt. Ger. Soc. Zool., 27: 97-106.

[12]. Forstner, N. and Wittman, G., (1983). Metal Pollution in the aquatic environment. Environ. Cont. Toxicol., 126: 456-460.

[13]. Gordon, C.; Yiannis, C.; Arthur, J. and Chris, D. (2000). Gonadal anomalies in the testicular tissue of white Perch, Morone americana collected in Coote's Paradise, lake Ontario Canada. SETAC 21st Annual Meeting, Nashville, Tennessee, 12-16 November.

[14]. Hatikakoty, G. (2002). Studies on certain aspects of the biology and habitat ecology of Oreochromis mossambicus (Peters) from a domestic pond in Upper Assam. Ph. D. Thesis., 130-133. Dibrugarh University, Dibrugarh.

[15]. Jayakumar, P. and Paul, V. (2006). Patterns of cadmium accumulation in selected tissues of the catfish Clarias batrachus (Linn.) exposed to sublethal concentration of cadmium chloride. Veterinarski Arhiv., 76: 167-177,

[16]. Kalay, M. and Canly, M. (2000). Elimination of essential $(\mathrm{Cu}, \mathrm{Zn})$ and nonessential $(\mathrm{Cd}, \mathrm{Pb})$ metals from tissue of a freshwater fish Tilapia zilli. Turk. J. Zool., 24: 429-436.

[17]. Khare, S. and Singh, S. (2002). Histopathological lesions induced by copper sulphate and lead nitrate in the gills of fresh water fish Nandus nandus. J. Ecotoxicol. Environ. Monit., 12, 105-111.

[18]. Kurnick, N. (1955). Pyronin Y in the methyl green pyronin histological stain. Stain Technol. 30: 213-230.

[19]. Langston, W. (1990). Toxic effects of metals and the incidence of marine ecosystems. Heavy Metals in the Marine Environment., CRC Press, New York., 256-260.

[20]. Luna, L. (1968). Histologic Staining Methods of The Armed Forces. Institute of pathology (ed.)., New York, McGrraw-HilBook., $180-185$.

[21]. Masson, P. (1929) Trichrome stainings and their preliminary technique. J. Tech Meth12:75-90.

[22]. McDonough, C. and Wenner, C. (2003). Growth, recruitment, and abundance of juvenile Mugil cephalus in South Carolina Estuaries. Fish. Bull., 101:343-357.

[23]. Mohamed, F. and Gad, N. (2008). Toxicological effects of three pesticides on the protein and lipid fish contents of tissues of Oreochromis niloticus. Egypt. J. Aquat. Biol. Fisher., 8: 111-133.

[24]. Mousa, S. and Mousa, M. (1999). Immunocytochemical and histological studies on the hypophyseal-gonadal system in the freshwater Nile tilapia, Oreochromis niloticus, during sexual maturation and spawning in different habitats. J. Exp. Zool., 284: 343354.

[25]. Murray, R. (1982). Ischemic Outline Series of Theory and Problems of Probability and Statistics. McGraw - Hill Book Company, Singapore.

[26]. Phillips, D. (1991). Selected trace elements and the use of abominators in subtropical and tropical marine ecosystems. Rev. Environ. Contam. Toxicol. J., 120: 105-129.

[27]. Roark, S. and Brown, K. (1996). Effects of metal contamination from mine tailings on allonym distributions of populations of great plains fishes. Environ. Toxicol. Chem., 15: 921-927.

[28]. Sanders, M. (1997). A field evaluation of the freshwater river crab, Potamonautes warreni, as a bioaccumulative indicator of metal pollution. Ph. D. Thesis, Rand Afrikaans University, South Africa., 215-220.

[29]. Subramanian, K. (1988). Lead in Quantitative Trace Analysis of Biological Materials. Mckenzie, H. and Smythe, A., Amsterdam., 325-335.

[30]. Weis, J. and Weis, P. (1989). Effects of environmental pollutants on early fish development. Rev. Aquat. Sci., 1: 45-73.

[31]. Wiegand, H.; Ottenwalder, H. and Bolt, H. (1985). Fast uptake kinetics in vitro of Cr (VI) by red blood cells of man and rat. Arch. Toxicol., 57: 31-34.

[32]. Yammamoto, K. and Yoshioka, H. (1964). Rhythm of development in the oocyte of the Oryzias latzes. Bull. Fac. Fish Hokkaido University., 15: 5-19.

[33]. Young, R. (2005). Toxicity Profiles. Toxicity summary for cadmium. Risk Assessment Information System, RAIS, University of Tennessee.

[34]. Zaki, M.; El-Shorbagy, I. and EI-Gharabawy, M. (1993). Histological characters of ovaries of Zebrasama xanthurum (Egypt). J. Appi. Sci., 6: 13-23.

[35]. Zottner R. and Seligson, A. (1964). Quoted from Hawk physiological chemistry, P1008 and 1134, published by Fata McGrawh, Publishing Company LTD. New Delhi. Clin. Chem., 10: 869-873.

\section{Explanation of Figures}


Figure 1: Cross section in D. labrax testis of Lake Bardawil showing seminiferous tubules (STU), spermatogonia (SG), spermatocytes (SC), spermducts (SD), spermatids (ST) and spermatozoa (SZ). Hx \& E. (X 250).

Figure 2: Cross section in D. labrax testis of Lake Manzalah showing seminiferous tubules (STU) and spermducts (SD). Hx \& E. (X 250).

Figure 3: Cross section in D. labrax testis of Lake Bardawil showing strongly stained PAS-positive materials: seminiferous tubules (STU), spermatogonia (SG), spermatocytes (SC), spermducts (SD), spermatids (ST) and spermatozoa (SZ). PAS reaction. (X 250).

Figure 4: Cross section in D. labrax testis of Lake Manzalah showing weakly stained PAS-positive materials: seminiferous tubules (STU) and spermducts (SD). PAS reaction. (X 250).

Figure 5: Cross section in D. labrax testis of Lake Bardawil showing strongly stained protein materials: seminiferous tubules (STU), spermatogonia (SG), spermatocytes (SC), spermducts (SD), spermatids (ST) and spermatozoa (SZ). Mercury-bromophenol blue. (X 250).

Figure 6: Cross section in D. labrax testis of Lake Manzalah showing weakly stained protein materials: seminiferous tubules (STU) and spermducts (SD). Mercury-bromophenol blue. (X 250).

Figure 7: Cross section in D. labrax testis of Lake Bardawil showing strongly stained DNA and RNA contents: seminiferous tubules (STU), spermatogonia (SG), spermatocytes (SC), spermducts (SD), spermatids (ST) and spermatozoa (SZ). Methyle green pyronin Y. (X 250).

Figure 8: Cross section in D. labrax testis of Lake Manzalah showing weakly stained DNA and RNA contents: seminiferous tubules (STU) and spermducts (SD). Methyle green pyronin Y. (X 250).

Figure 9: Cross section in D. labrax testis of Lake Bardawil showing weakly stained collagen fibres: seminiferous tubules (STU), spermatogonia (SG), spermatocytes (SC), spermducts (SD), spermatids (ST) and spermatozoa (SZ). Masson trichrome stain. (X 250).

Figure 10: Cross section in D. labrax testis of Lake Manzalah showing strongly stained collagen fibres: seminiferous tubules (STU) and spermducts (SD). Masson trichrome stain. (Orig. magn. X 250).

Figure 11: Cross section in D. labrax ovary of Lake Bardawil showing tunica albuginea (TA), oogonia (O), ovarian follicles (OF), yolk spheres (YS), lipid vesicles (L), cortical alveoli (CA), granulose cell layers (GCL) and theca cell layers (TCL). Hx \& E. (X 250).

Figure 12: Cross section in D. labrax ovary of Lake Manzalah showing broken tunica albuginea (BTA), atresia (AT), vacuoles (V), deformed zona radiate (DZR) and necrosis of germ cells (NGC). Hx \& E. (X 250).

Figure 13: Cross section in D. labrax ovary of Lake Bardawil showing strongly stained PAS-positive materials: tunica albuginea (TA), oogonia (O), ovarian follicle (OF), yolk spheres (YS), lipid vesicles (L), cortical alveoli (CA), granulose cell layers (GCL) and theca cell layers (TCL). PAS reaction. (X 250).

Figure 14: Cross section in D. labrax ovary of Lake Manzalah showing weakly stained PAS-positive materials: broken tunica albuginea (BTA), necrosis of germ cells (NGC), atresia (AT), vacuoles (V) and deformed zona radiata (DZ). PAS reaction. (X 250).

Figure 15: Cross section in D. labrax ovary of Lake Bardawil showing strongly stained protein materials: tunica albuginea (TA), oogonia (O), ovarian follicles (OF), yolk spheres (YS), lipid vesicles (L), cortical alveoli (CA), granulose cell layers (GCL) and theca cell layers (TCL). Mercury-bromophenol blue. (X 250).

Figure 16: Cross section in D. labrax ovary of Lake Manzalah showing weakly stained protein materials: broken tunica albuginea (BTA), necrosis of germ cells (NGC), atresia (AT), vacuoles (V) and deformed zona radiata (DZR). Mercury-bromophenol blue. (X 250).

Figure 17: Cross section in D. labrax ovary of Lake Bardawil showing strongly DNA and RNA contents: tunica albuginea (TA), oogonia (O), ovarian follicles (OF), yolk spheres (YS), lipid vesicles (L), cortical alveoli (CA), granulose cell layers (GCL) and theca cell layers (TCL). Masson trichrome stain. (X 250).

Figure 18: Cross section in D. labrax ovary of Lake Manzalah showing weakly DNA and RNA contents: broken tunica albuginea (BTA), necrosis of germ cells (NGC), atresia (AT), vacuoles (V) and deformed zona radiata (DZR). Masson trichrome stain. (X 250).

Figure 19: Cross section in D. labrax ovary of Lake Bardawil showing strongly stained collagen fibres: tunica albuginea (TA), oogonia (O), ovarian follicles (OF), yolk spheres (YS), lipid vesicles (L), cortical alveoli (CA), granulose cell layers (GCL) and theca cell layers (TCL). Masson trichrome stain. (X 250).

Figure 20: Cross section in D. labrax ovary of Lake Manzalah showing weakly stained collagen fibres: broken tunica albuginea (BTA), necrosis of germ cells (NGC), atresia (AT), vacuoles (V) and deformed zona radiata (DZR). Masson trichrome stain. (X 250). 

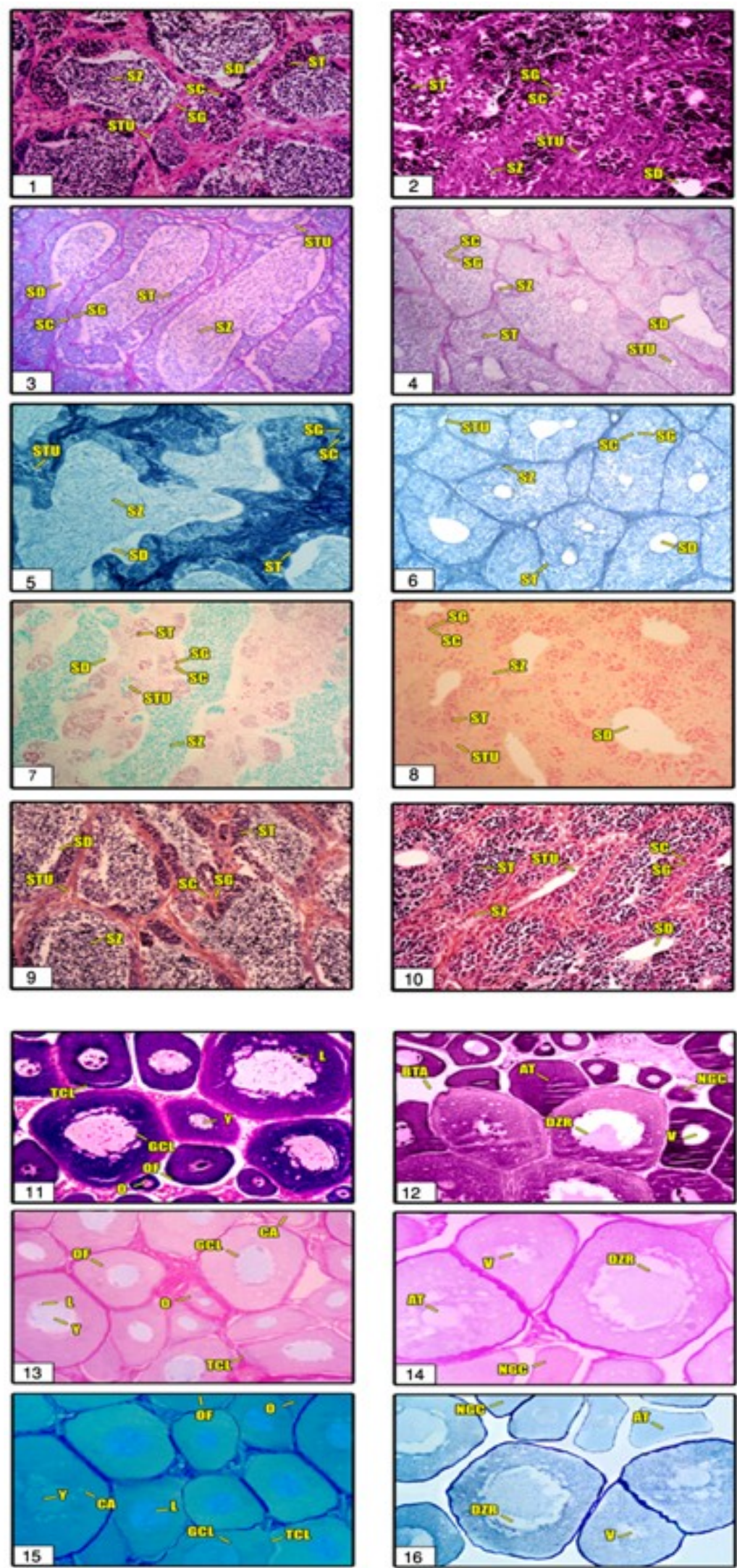

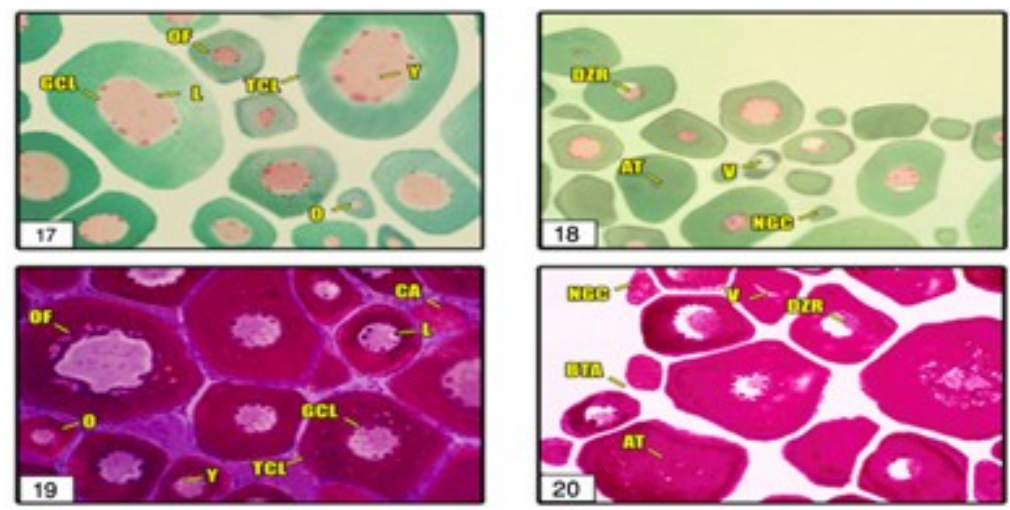

\begin{tabular}{|c|c|c|c|c|c|c|}
\hline & \multicolumn{6}{|c|}{ Element } \\
\hline & \multicolumn{2}{|c|}{$\mathbf{C r}$} & \multicolumn{2}{|c|}{$\mathbf{P b}$} & \multicolumn{2}{|c|}{ Cd } \\
\hline Lake & B & $\mathbf{M}$ & B & $\mathbf{M}$ & B & M \\
\hline Mean & 0.0115 & 0.245 & 0.015 & 0.0945 & 0.00142 & 0.065 \\
\hline Standard Deviation & 0.42157 & 0.04713 & 0.0315 & 0.0215 & 0.0436 & 0.04281 \\
\hline Standard Error & 0.00245 & 0.0236 & 0.0185 & 0.0016 & 0.0218 & 0.002015 \\
\hline t-Test & \multicolumn{2}{|c|}{0.00481} & \multicolumn{2}{|c|}{0.00284} & \multicolumn{2}{|c|}{0.00271} \\
\hline Significance & \multicolumn{2}{|c|}{$* *$} & \multicolumn{2}{|c|}{$* *$} & \multicolumn{2}{|c|}{$* *$} \\
\hline
\end{tabular}

Expla Nation Of Tables

Table (1): Showing the mean concentrations (ppm) of $\mathrm{Cr}, \mathrm{Pb}$ and $\mathrm{Cd}$ in water of Lake Bardawil and Lake Manzalah; Winter, 2012.

Lake Bardawil is a protected area, so it is considered as the control lake $n=6$

\begin{tabular}{|l|l|l|c|}
\hline- & Non Significant & $\mathrm{P}>0.05$ & $\begin{array}{c}\mathrm{M} \\
\text { Manzalah }\end{array}$ \\
\hline$*$ & Significant & $0.01 \leq \mathrm{P} \leq 0.05$ & \\
\hline$* *$ & High Significant & $\mathrm{P}<0.01$ & $\begin{array}{c}\mathrm{B} \\
\text { Bardawil }\end{array}$ \\
\hline
\end{tabular}

